\title{
Complex treatment of patient with STE myocardial infarction - according to New ESC STEMI guidelines 2017.
}

\author{
Miloš Trajković́ Aleksandar Davidović2, Snežana Bjelići ${ }^{1}$ Lućia Simona Oalđe ${ }^{1}$, Branislav \\ Crnomarković ${ }^{1}$; Ilija Srdanović1,3 \\ ${ }^{1}$ Cardiology Clinic, Institute for Cardiovascular Diseases of Vojvodina, Sremska Kamenica, Serbia, ${ }^{2}$ Clinical-Hospital \\ Center Zvezdara-Belgrade, ${ }^{3}$ School of Medicine, Novi Sad University, Novi Sad, Serbia.
}

Abstract

\begin{abstract}
Introduction: In many aspects of STEMI patient treatment there are the clear guideline according to many scientific evidence from excellent designed and performed large randomized clinical studies. However there is still some gray zones of knowledge and scientific fields in which exist no answered questions.

Case report: Male patient age 68 has been admitted to Cardiology Clinic, Institute for Cardiovascular Diseases of Vojvodina, Sremska Kamenica due to typical chest pain and electrocardiography (ECG) signs of STEMI anterolateral region. The patient is hospitalized in center for PPCI with time delay of 210 minute, dominantly due to no adequate organization of medical service. Immediate after the admission primary percutaneous intervention (PPCI) was performed at distal tip of venous graft for obtuse branch of LCx with drug eluting stent (DES) implantation with the minimum intrahospital time delay. Hospital course was complicated by heart failure, atrial fibrillation, and thrombus in the left ventricle.

Conclusion: Timely diagnosis of STEMI and good organization of medical service at all level is the key to successful care, and the prevention of time delay in establishing diagnosis and adequate therapeutic activities remains an imperative in the treatment of patients with STEMI.
\end{abstract}

Key words STEMI, percutaneous coronary intervention, time delay, treatment

\section{Introduction}

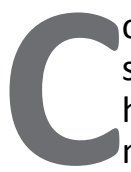
oronary artery disease (CAD) is the leading cause of death worldwide. Incidence of this form of heart disease is still increasing. However in some of European countries in the past three decades is noticed decrease mortality from CAD. ${ }^{1,2}$

New modalities of diagnostic workup and protocols of treatment for patients with acute myocardial infarction with permanent ST elevation (STEMI) is susceptible for many changes according to many scientific achievements. The new Guidelines for treatment patients with STEMI announced and published in September 2017 give us some new insight in this field of cardiology praxis.

In many aspects of STEMI patient treatment there are the clear guideline according to many scientific evidence from excellent designed and performed large randomized clinical studies. However there is still some gray zones of knowledge and scientific fields in which exist no answered questions. Some treatment options are under observation and provide doubtful questions.

How to shorter the time delay to make diagnosis, reperfusion strategy, optimal approach to perform coronarography, how to treat patient with acute heart fail- ure, optimal duration of dual and introduction triple antithrombotic therapy if thromboembolic event appears and its duration, how to treat non culprit vessel and many more questions are the possible problems to deal with.

\section{Case report}

Male patient age 68 has been admitted to Clinic of Cardiology in our Institution due to typical anginal chest pain and electrocardiography (ECG) signs of STEMI anterolateral region. Patient was transferred from regional hospital where he was previously admitted due to acute metabolic decompensation of diabetes mellitus. The patient confirmed history of hypertension and type 2 diabetes mellitus (T2DM) more than a decade.

Due to angina complains the patient has been treated in the year of 2010 with surgical revascularization procedure with double aorto-coronary by pass, with grafting right coronary artery (RCA) and obtuse branch of left circumflex coronary artery (LCX).

The first symptoms of typical chest pain start on $1^{\text {st }}$ February 2018 at around 18.00. The chest pain was associated with profuse swelling and dyspnea. ECG at the time of admission in regional hospital at $1^{\text {st }}$ February 


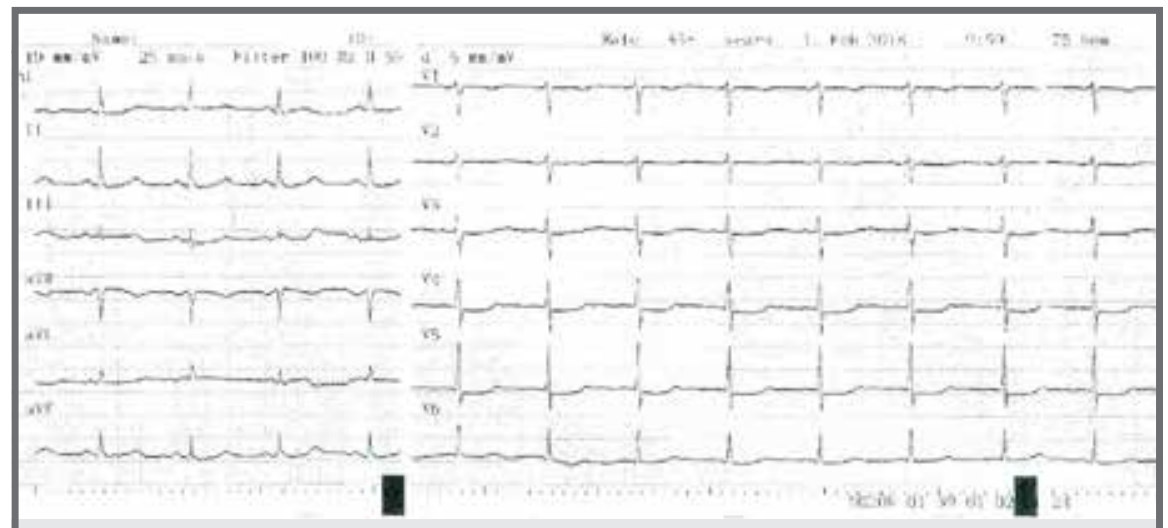

Figure 1. ECG at the addmision in regional hospital due to decompensated T2DM

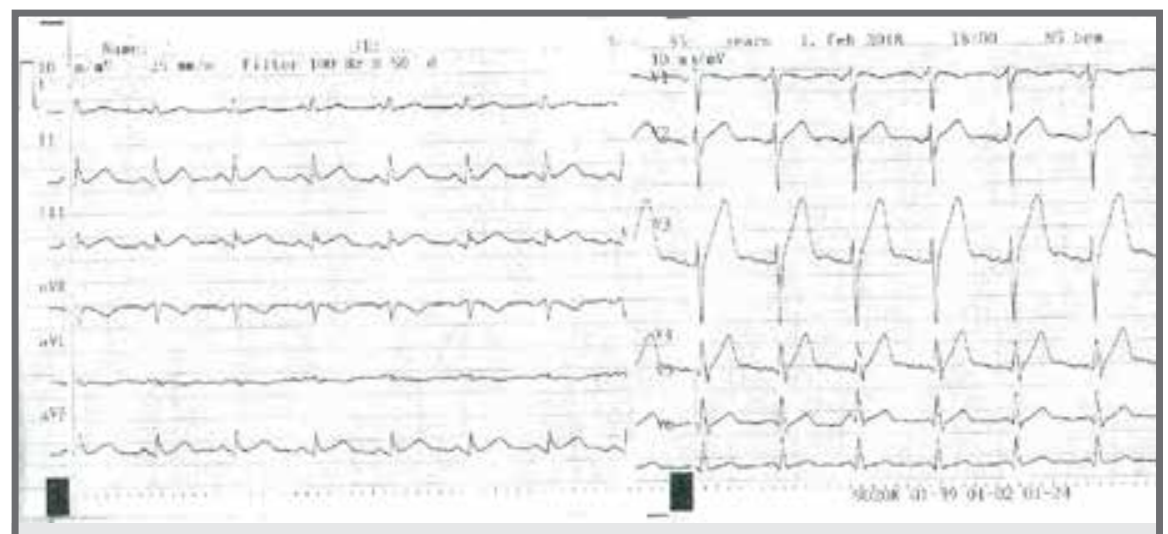

Figure 2. ECG several minutes after the chest pain started in regional hospital

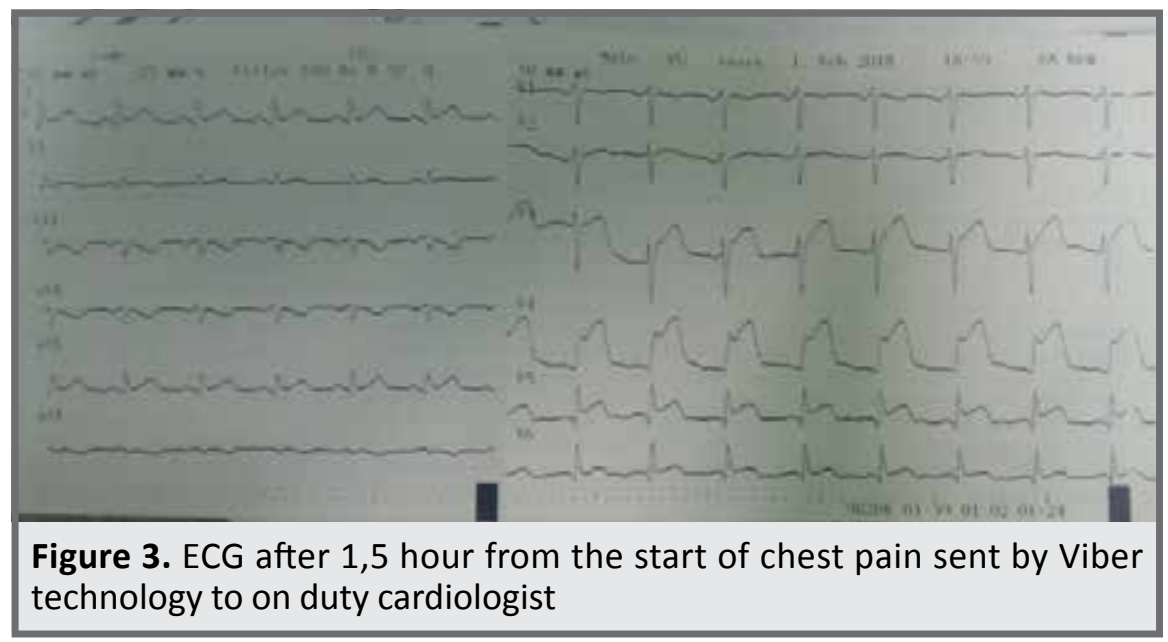

2018 at 9.59 hour and 6 p.m. as well as at 19.30 hour our display at Figures 1,2 and 3. During the period of observation in regional hospital some diagnostic work up was performed. Laboratory tests performed after the chest pain started revealed enlarged level of high sensitive troponin I and CPK MB isoenzyme (TnI $33639 \mathrm{ng} / \mathrm{l}$, CK-MB 246,9 ng/ml). According to this clinical scenario the patient gets $300 \mathrm{mg}$ of aspirin oral.

According to ECG displayed at Figure 2 and 3, at 19.39 hour by telephone has been consulted on duty cardiologist in our institution. During telephone consultation ECG recordings has been presented to our on duty cardiology via Viber technology. Immediate transfer to our cardiology Clinic was suggested.
The patient arrived to our emergency department (ED) at 21.30 hour or some 3.5 hour or 210 minutes after the symptoms of STEMI started.

At the admission in our hospital the patient was dyspnoic with mild increased respiratory rate of 18$20 / \mathrm{min}$., with basal rales on lungs with oxygen saturation of $91 \%$. Blood preassure $140 / 80 \mathrm{mmHg}$, sinus rhythm rate $90 / \mathrm{min}$. According to this findings patient at the moment at admission was in Killip 2 functional class.

The patient was pretreated in our ED with loading dose of ticagrelor of $180 \mathrm{mg}$ oral, $20 \mathrm{mg}$ of i.v. furosemide. Immediate after he was transferred to catheterization laboratory for emergency coronarography. 

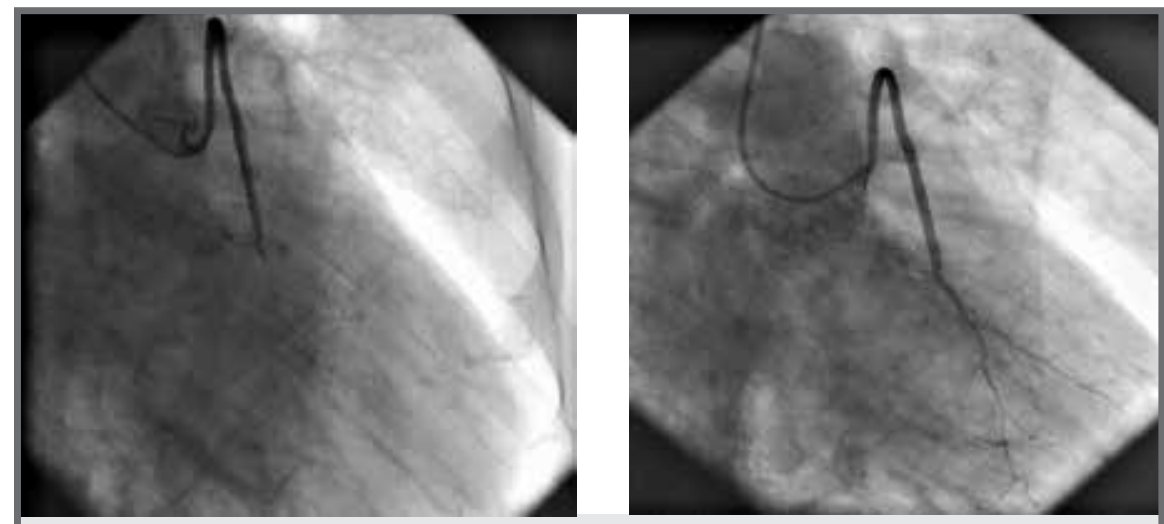

Figure 4. a) occlusion of obtuse marginal branch LCx and b) final results after stent implantation

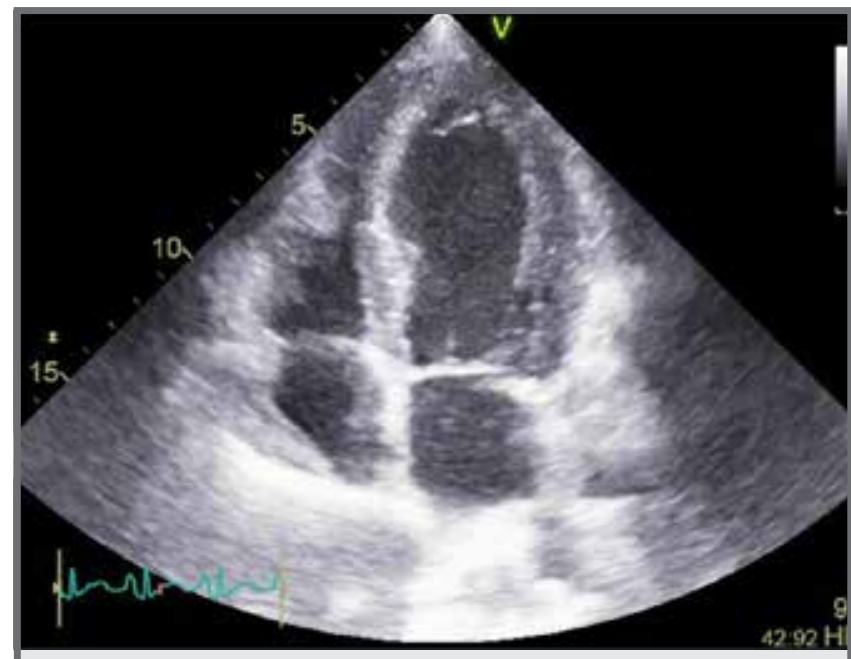

Figure 5. 4CH transthoracic echocardiography

At 21:46 hour the patient was in catheterization laboratory and 5 minutes later $6 \mathrm{Fr}$ arterial sheet was introduced in right radial artery. Coronarography revealed significant stenotic lesions of native left anterior descending coronary artery (LAD) with 70-90\% stenosis. The native RCA and obtuse marginal branch were with chronic total occlusions (CTO). Venous graft for RCA was patent with no stenotic lesion and infarct related artery was targeted as distal segment of venous graft for obtuse marginal branch of LCx at the point of attachment to obtuse marginal branch.

Immediate after was performed primary percutaneous intervention (PPCI) at distal tip of venous graft for obtuse branch of LCx with drug eluting stent (DES) implantation, with optimal result. TIMI flow 3 was achieved. During the procedure $380 \mathrm{ml}$ of contrast agent has been used, 24 minute of $X$-ray exposure and total irradiation of $703 \mathrm{mGy}$.

After the procedure due to progression of heart failure to level of acute pulmonary oedema, the patient was transferred to intensive coronary care unit ( ICCU). His vital signs deteriorate rapidly, respiratory rate 25-28/ min., heart rate of $100 / \mathrm{min}$., oxygen saturation to $88 \%$, and lactate level of $2.2 \mathrm{mmol} / \mathrm{l}$. With additional $40 \mathrm{mg}$ of furosemide, spironolactone of $50 \mathrm{mg}$, oxygen via facial mask with flow of $4 \mathrm{l} / \mathrm{min}$. was added.

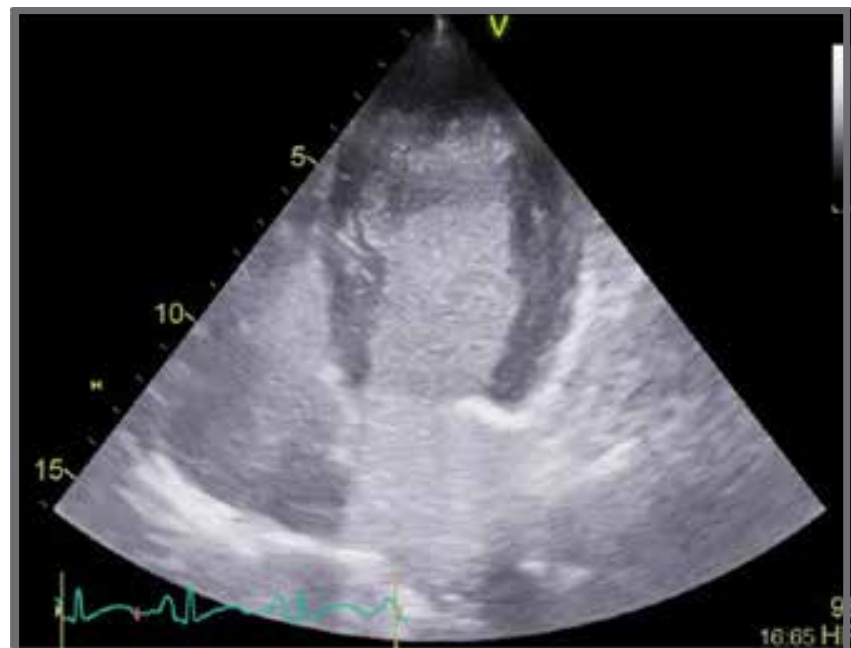

Figure 6. 4CH transthoracic transpulmonary contrast echocardiography

All this measures gives the results and rapid clinical stabilisation was achieved. After 12 initial hours of treatment the patent was clinical stabile enough and transferred to semi-intensive intensive department.

Echocardiography at the first day revealed significant reduction of both systolic diastolic function of left ventricle. Initial estimation was on about 25-30 \% left ventricle ejection fraction (LVEF) with highly suspicious apical thrombotic material (Figure 5). According to that finding additional transpulmonal contrast echocardiography was performed (Figure 6). Contrast echocardiography enable more accurate endocard visualization and confirmed thrombotic material in apical segment of left ventricle and even worse systolic function of left ventricle with approximate EFLV around $20 \%$.

Due to visualized thrombus with high embologenic potential, low molecular weight heparin (LMWH) was introduced in therapeutic dose. First dose of beta blocker was introduced in dose of $1,25 \mathrm{mg}$ oraly bisoprolol and zofenopril 3,25 $\mathrm{mg}$ twice daily.

At the second day or 30 hour after the admition clinical state deteriorate. The patient start to be mental agitated and atrial fibrillation with rapid ventricular rate appeared (Figure 6). After the introduction of amiodarone and additional beta blocker therapy successful conversion to sinus rhythm has been achieved. How- 


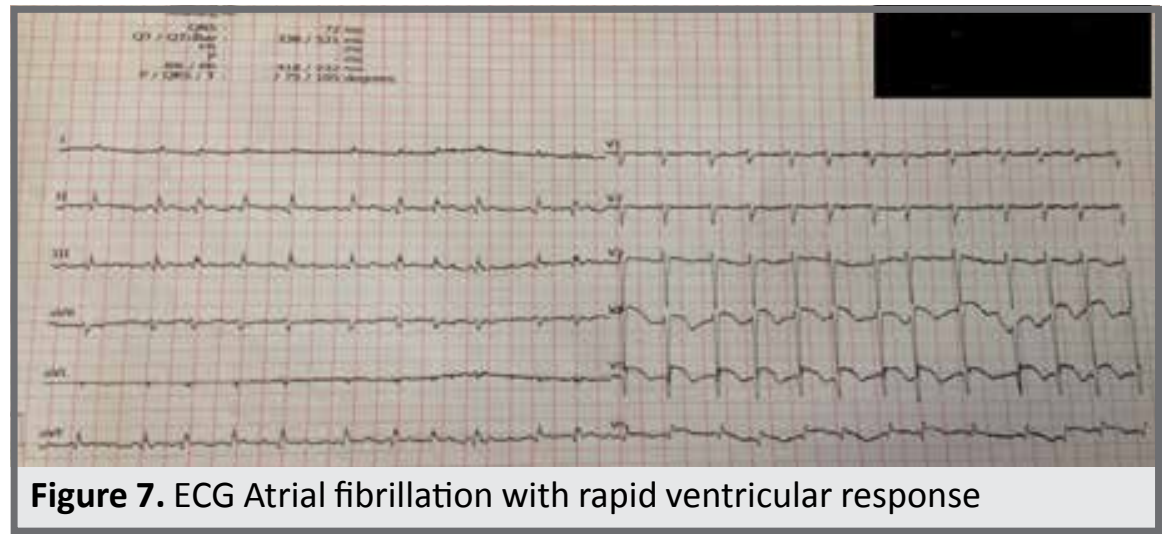

ever paroxysmal events of atrial fibrillation and flluter were noticed and at $3^{\text {rd }}$ and $4^{\text {th }}$ day of hospitalization. All those rhythm disturbances have been successfully converted with medicament interventions. By estimating the thrombotic and potential bleeding risk with CHA2DS2-VASc score value of 4 , and HAS-BLED score of 2 , triple antithrombotic therapy was introduced according to at least two indications, atrial fibrillation and visualized thrombus in left ventricle. The antiplatelet therapy was switched to klopidogrel $75 \mathrm{mg}$, and LMWH followed by oral anticoagulant therapy with warfarin.

Further clinical course went without complications. According to lack of evident ongoing ischemia there was no indication for repeat coronarography or additional revascularization procedure. Heart team indicate additional functional investigation for eventual rest coronary ischemia in the follow up by stress echocardiography examination.

The patient was discharged from hospital after 11 days of hospital stay, with no clinical complains in stabile heart- sinus rhythm. Triple antithrombotic therapy (clopidogrel, aspirin, warfarin) was proposed for at least1 month. Other therapy consists beta blockers ( bisoprolol), amiodarone, ACE inhibitor (zofenopril), statin (rosuvastain), diuretic (furosemide + spironolactone) and insulin and proton pump inhibitor (pantoprasol).

\section{Discussion}

Timely diagnosis of STEMI is key of successful treatment, starts with first medical contact (FMC). In accordance with modern European guidelines, 12-channel ECG must be done at the place of FMC, with ten minutes of delay. In addition, ECG monitoring is recommended with all patients with suspicious for STEMI. Routine blood samples for cardiac-specific enzymes is also recommended, but its results or not needed to start reperfusion therapy. ${ }^{2-7}$

In this case, patient had immediately reported chest pains, and time from FMC to first ECG was less than ten minutes. However, clearly ECG signs of STEMI was not recognized and caused delay initial time delay added with not necessary laboratory diagnostic workout, not recommended in case of evident ECG changes such as ST elevation.

Considering that PPCl was feasible within 120 min, transfer to primary $\mathrm{PCl}$ center was indicated. Patient was admitted at ED after 3.5 hours from reported chest pains. Patient was transferred from ED, directly to catheterization laboratory. This approach is strongly recommended according to some data from hospitals with high volume in PPCl in United States. ${ }^{8,9}$

From the above, we can conclude that total ischemic time was 3 hour and $45 \mathrm{~min}$, whereby patient delay in this case was minimal. Delay to establish definite diagnosis and transportation time was unacceptable too long. According to guidelines recommendations for intra hospital delay in $\mathrm{PCl}$ center have to be as shorter as possible. In our case the longest time delay was due to adequate analysis of ECG records and the transport organization of the patient to $\mathrm{PPCl}$ center. Knowing that nearest $\mathrm{PPCl}$ center is within $7 \mathrm{~km}$ away from regional hospital, the total time delay due to medical system of 210 minutes was extreme long.

Coronarography, graftography and in the same act $\mathrm{PPCl}$, was performed by radial approach, with implantation of DES in venous graft for obtuse branch of LCX . Transradial approach in PPCl is feasible and safer in patients with aorto-coronary by-pass grafts. Percent of positive outcome of intervention is similar between transradial and transfemoral approach, but transradial approach is connected with lower rank of severe vascular complications. ${ }^{10}$

Interventional cardiologists often choose radial approach because of experience and smaller risk of bleeding complications. ${ }^{11-14}$

Decision of DES implantation is made according to relevant guidelines. Latest generations of DES showed grater safeness and even better efficiency, especially when it comes to reducing risk of stent-thrombosis and re infarction. ${ }^{2,15}$

Based on meta-analysis results, routine thrombus aspiration during $\mathrm{PPCl}$ is not recommended, but in case of larger thrombus mass after opening of coronary artery one should consider. ${ }^{16}$

The use of GP IIb / IIla inhibitors should be considered as an auxiliary treatment strategy before, during and after the $\mathrm{PCl}$, if there is no flow in the open artery or thrombotic complications are present. ${ }^{17}$ In this case, after the intervention an optimal result was achieved and without thrombotic complications, the therapy was not applied.

According to relevant guidelines, patients with STE$\mathrm{MI}$ and multi vessel disease, revascularisation of lesions on non-infarction arteries should be considered before discharge. ${ }^{18,19,20}$ Because of significant changes of LAD, 
in this case, ambulatory functional estimation is indicated in irrigation area of LAD.

A further course of patient hospitalization is complicated by heart failure, the onset of stagnant blood in the left ventricle and the presence of microthrombus between trabecula, and then by the onset of paroxysm of atrial fibrillation.

In accordance with relevant guidelines, therapy for the treatment of acute heart failure was applied, with the use of therapeutic doses of parenteral anticoagulant therapy.

Following guidelines for STEMI 2017. within treatment of heart failure, oxygen therapy is recommended with $\mathrm{SpO} 2<90 \%$. Although the benefit of oxygen therapy in patients with STEMI, who are hypoxic is undisputed, the use of oxygen in non-hypoxic patients is still controversial. ${ }^{21} \mathrm{~A}$ new randomized study showed that routine oxygen administration in normoxic patients with STEMI did not show any benefit over a one-year mortality. $^{22}$ There are practically no clear randomized studies that support the routine use of oxygen in patients with acute IM, and the harmful effect cannot be excluded. ${ }^{23}$

Because patient had several episodes of paroxysmal atrial fibrillation and suspected microthrombus in the left ventricle, in addition to the application of dual antiplatelet therapy, oral anticoagulant therapy (OAT) was also added, which is confirmed by calculated scores (HAS-BLED and CHA2DS2-VASc). According to relevant guidelines, triple therapy should be considered - (aspirin, clopidogrel, OAT) for one to six month to patients who have an indication for taking OAT, and who have been under $\mathrm{PCl}$, regardless of the type of stent.

If there is a large ischemic risk due to acute coronary syndrome or other anatomic/procedural characteristics, it is necessary to consider giving triple therapy for more than a month, up to 6 months. ${ }^{24}$ Suspension of antiplatelet therapy should be considered after 12 months. ${ }^{25}$

However, despite a large number of studies, it remains unclear what is the best decision of antithrombotic therapy in patients who have indication for OAT and antiplatelet therapy at the same time.

\section{Conclusion}

Timely diagnosis of STEMI, and good organization of medical service at all level is the key to successful care, and the prevention of delay remains an imperative in the treatment of patients with STEMI, in order to reduce the occurrence of complications and to improve the clinical course and outcome of the disease.

\section{Literature}

1. Hartley A, Marshall DC, Salciccioli JD, et al. Trends in mortality from ischemic heart disease and cerebrovascular disease in Europe: 1980 to 2009. Circulation 2016;133(20):1916-1926.

2. Ibanez B, James S, Agewall S, et al. European Heart Journal, Volume 39, Issue 2, 7 January 2018, Pages 119-177.

3. Diercks DB, Peacock WF, Hiestand BC, et al. Frequency and consequences of recording an electrocardiogram $>10$ minutes after arrival in an emergency room in non-ST-segment elevation acute coronary syndromes (from the CRUSADE Initiative). Am J Cardiol 2006;97(4):437-442.
4. Rokos IC, French WJ, Koenig WJ, et al. Integration of pre-hospital electrocardiograms and ST-elevation myocardial infarction receiving center (SRC) networks: impact on door-to-balloon times across 10 independent regions. JACC Cardiovasc Interv 2009; 2(4):339-346.

5. Mehta RH, Starr AZ, Lopes RD, et al. Incidence of and outcomes associated with ventricular tachycardia or fibrillation in patients undergoing primary percutaneous coronary intervention. JAMA 2009;301(17):1779-1789.

6. Rokos IC, Farkouh ME, Reiffel J, et al. Correlation between index electrocardiographic patterns and pre-intervention angiographic findings: insights from the HORIZONS-AMI trial. Catheter Cardiovasc Interv 2012;79(7):1092-1098.

7. Thygesen K, Alpert JS, Jaffe AS, et al. Writing Group on the Joint ESC/ACCF/AHA/WHF Task Force for the Universal Definition of Myocardial Infarction, Thygesen K, Alpert JS, White HD, et al. ESC Committee for Practice Guidelines. Third universal definition of myocardial infarction. Eur Heart J 2012;33(20):2551-2567.

8. Chan AW, Kornder J, Elliott $\mathrm{H}$, et al. Improved survival associated with pre-hospital triage strategy in a large regional ST-segment elevation myocardial infarction program. JACC Cardiovasc Interv 2012;5(12):1239-46.

9. Bagai A, Jollis JG, Dauerman HL, et al. Emergency department bypass for ST-segment-elevation myocardial infarction patients identified with a prehospital electrocardiogram: a report from the American Heart Association Mission: Lifeline program. Circulation 2013;128(4):352-359.

10. Pei-Yuan He, Yue-Jin Yang, Shu-Bin Qiao,et al. A Comparison of the Transradial and Transfemoral Approaches for the Angiography and Intervention in Patients with a History of Coronary Artery Bypass Surgery: In-hospital and 1-year Follow-up Results. Chin Med J (Engl). 2015 Mar 20; 128(6): 762-767.

11. Valgimigli M, Gagnor A, Calabro P, et al. MATRIX Investigators. Radial versus femoral access in patients with acute coronary syndromes undergoing invasive management: a randomised multicentre trial. Lancet 2015;385(9986):2465-2476.

12. Jolly SS, Yusuf S, Cairns J, et al. RIVAL Trial Group. Radial versus femoral access for coronary angiography and intervention in patients with acute coronary syndromes (RIVAL): a randomised, parallel group, multicentre trial. Lancet 2011;377(9775):1409-1420.

13. Romagnoli E, Biondi-Zoccai G, Sciahbasi A, et al. Radial versus femoral randomized investigation in ST-segment elevation acute coronary syndrome: the RIFLE-STEACS (Radial Versus Femoral Randomized Investigation in ST-Elevation Acute Coronary Syndrome) study. J Am Coll Cardiol 2012;60(24):2481-2489.

14. Karrowni W, Vyas A, Giacomino B, et al. Radial versus femoral access for primary percutaneous interventions in ST-segment elevation myocardial infarction patients: a meta-analysis of randomized controlled trials. JACC Cardiovasc Interv 2013;6(8):814-823.

15. Kastrati A, Dibra A, Spaulding $C$, et al. Meta-analysis of randomized trials on drug-eluting stents vs. bare-metal stents in patients with acute myocardial infarction. Eur Heart J 2007;28(22):2706-2713

16. Sabate $M$, Brugaletta $S$, Cequier $A$, et al. Clinical outcomes in patients with ST-segment elevation myocardial infarction treated with everolimus-eluting stents versus bare-metal stents (EXAMINATION): 5-year results of a randomised trial. Lancet 2016; 387(10016):357-366)

17. ten Berg JM, van t Hof AW, Dill T, et al. Effect of early, pre-hospital initiation of high bolus dose tirofiban in patients with STsegment elevation myocardial infarction on short- and long-term clinical outcome. J Am Coll Cardiol 2010;55(22):2446-2455)

18. Moreno R, Mehta SR. Nonculprit vessel intervention: let's COMPLETE the evidence. Rev Esp Cardiol (English Ed) 2017;70:418-420.

19. Bangalore S, Toklu B, Wetterslev J. Complete versus culprit-only revascularization for ST-segment-elevation myocardial infarction and multivessel disease: a meta-analysis and trial sequential analysis of randomized trials. Circ Cardiovasc Interv 2015; 8(4): e002142.

20. Elgendy IY, Mahmoud AN, Kumbhani DJ, et al. Complete or culprit-only revascularization for patients with multivessel coronary artery disease undergoing percutaneous coronary intervention: a pairwise and network meta-analysis of randomized trials. JACC Cardiovasc Interv 2017;10(4):315-324. 
21. Loscalzo J. Is oxygen therapy beneficial in acute myocardial infarction? Simple question, complicated mechanism, simple answer. N Engl J Med. 2017; OI:10.1056/NEJMoa1706222.

22. Hofmann R, James, SK, Jernberg T, et al. for the DETO2X-SWEDEHEART Investigators. Oxygen therapy in suspected acute myocardial infarction. N Engl J Med. 2017; DOI: 10.1056/NEJMoa 1706222.

23. Cabello JB, Burls A, Emparanza JI, et al. Oxygen therapy for acute myocardial infarction. Cochrane Database Syst Rev 2016; CD007160.
24. Fiedler KA, Maeng M, Mehilli J, et al. Duration of triple therapy in patients requiring oral anticoagulation after drug-eluting stent implantation: the ISAR-TRIPLE trial. J Am Coll Cardiol 2015; 65:1619-1629.

25. Lamberts M, Gislason GH, Lip GY, et al. Antiplatelet therapy for stable coronary artery disease in atrial fibrillation patients taking an oral anticoagulant: a nationwide cohort study. Circulation 2014;129:1577

\section{Sažetak}

Lečenje kompleksnog bolesnika sa infarktom miokarda sa ST elevacijom - prema ESC preporukama za tretman bolesnika sa STEMI iz 2017

Miloš Trajković Aleksandar Davidović2 , Snežana Bjelić1, Lućia Simona Oalđe ${ }^{1}$, Branislav Crnomarković1, Ilija Srdanović1,3

${ }^{1}$ Klinika za kardiologiju, Institut za kardiovaskularne bolesti Vojvodine, Sremska Kamenica, Srbija, ${ }^{2}$ Kliničko bolnički centar Zvezdara-Beograd, ${ }^{3}$ Medicinski fakultet, Univerzitet u Novom Sadu, Novi Sad, Srbija

Uvod: U mnogim aspektima tretmana STEMI pacijenata postoje jasna uputstva prema mnogim naučnim dokazima iz odlično dizajniranih i izvedenih velikih randomizovanih kliničkih studija. Međutim i dalje postoje tzv. sive zone u saznanjima i naukom neodgovorena pitanja.

Prikaz slučaja: Muškarac starosti 68 je primljen na Kliniku za kardiologiju, Instituta za kardiovaskularne bolesti Vojvodine, Sremska Kamenica zbog tipičnih bolova u grudima i elektrokardiografskih (EKG) znakova STEMI anterolateralne regije. Pacijent je hospitalizovan u centru za PPCI sa kašnjenjem od ukupno 210 minuta nakon početka simptoma STEMI-a, dominantno zbog kašnjenja u organizaciji zdravstven službe. Urađenom primarnom perkutanom koronarno intervencijom (PPCI) na distalnom kraju venskog grafta za LCx sa implantacijom lekom obloženog stenta (DES) ostvaren je sa minimalnim gubitkom intrahospitalnog vremena zbrinjavanja. Bolnički tok je komplikovan srčanom insuficijencijom, atrijalnom fibrilacijom i trombom u levoj komori.

Zaključak: Pravovremena dijagnoza STEMI- i dobra organizacija svih delova zdravstvenog sistema je ključ uspešnog lečenja, a prevencija vremena odlaganja postavljanja dijagnoze i ispravnih terapijskih postupaka, ostaju imperativ u lečenju bolesnika sa STEMI.

Ključne reči: STEMI, perkutana koronarna intervencija, vreme odlaganja, lečenje 